\title{
Ortodontia do futuro: da ficção à realidade
}

Isaac Asimov, escritor e mestre de ficção científica, disse uma vez, em uma palestra: "Quem escreve ficção científica não pode evitar fazer previsões - não de algo que vai ocorrer, mas do que pode ocorrer". Como pesquisadores, em fato, frequentemente têm a obrigação de vasculhar o presente para jogar luz no futuro, poderíamos modestamente - nos comparar a escritores de ficção científica. E é essa a posição que assumirei a partir de agora nesse editorial. Responderei a uma pergunta que recentemente foi feita a mim.

\section{Como estará a Ortodontia daqui a 30 anos?}

Em 30 anos, a World Federation of Orthodontists (WFO) terá estabelecido orientações para o conteúdo programático de cursos de pósgraduação em Ortodontia de todo o mundo. $O$ número de cursos com baixa carga horária, nos países com maior desenvolvimento da educação, terá caído dramaticamente. Nesses países, os cursos tenderão a ter duração de 2 a 3 anos em tempo integral. Entidades como o Board Brasileiro de Ortodontia e o Board Americano de Ortodontia serão fundamentais no processo de checagem da qualidade dos profissionais formados. A comunidade ortodôntica se tornará mais global. Aulas interativas serão assistidas simultaneamente por alunos espalhados pelo globo.

Uma maior capacitação em informática será fundamental para a prática da especialidade. Modelos de estudo serão digitais, não apenas para acelerar o processo de confecção e análise, mas também porque os custos de armazenamento dos modelos de gesso se tornarão exorbitantemente altos nas principais cidades do mundo. Impressoras tridimensionais serão utilizadas sempre e quando modelos físicos forem necessários. Mas existirão outras razões para o aprofundamento em informática.
Métodos de sobreposição de imagens tridimensionais serão rotineiros. Os alunos de Ortodontia terão acesso a artigos com melhor desenho e a evidência científica tomará mais corpo. Como uma das consequências, racionalizaremos o uso dos raios $X$ nos exames de imagem.

Os avanços tecnológicos permitirão individualizações de tratamento com mais facilidade e, consequentemente, será possível atender mais pessoas em menos tempo, com alto nível de excelência. Isso implicará em maior acesso ao tratamento pela população. Também levará a ajustes óbvios. Países, como o Brasil, que já contam com mais cirurgiões-dentistas do que requerem as necessidades de saúde bucal, terão encolhido o tamanho do sistema educacional odontológico.

A prática clínica ortodôntica sofrerá mudanças também. A informática se inserirá dentro do atendimento ao paciente, auxiliando o fluxo de trabalho. Sistemas de controle dos movimentos dentários alertarão o ortodontista sempre que ele se distanciar dos objetivos do tratamento ou demorar para tomar as medidas terapêuticas necessárias. Os pacientes, por sua vez, serão mais interativos com o tratamento, tomando decisões ainda mais esclarecidas sobre o que será feito neles.

Todos os aspectos aqui discutidos conduzirão a um único ponto: a Ortodontia aumentará a qualidade da assistência prestada e o impacto positivo na vida da população global.

Muitos talvez estejam se perguntando, nesse momento, qual a relação dessa ficção com a Ortodontia atual. A resposta é que ela é total. É claro que resenhei apenas um possível cenário futuro, entretanto, a imagem criada já está sendo desenhada nesse momento e o mais preocupante disso é que muitos jovens profissionais não estão atentos para esse fato. 
Modelos digitais já são uma realidade tangível a preços acessíveis. Além disso, profissionais estão incorporando-os à rotina clínica, realizando set-ups virtuais e incrementando suas aulas e apresentações para pacientes. Métodos como o apresentado por Motta et al., no presente número do jornal, para a sobreposição de imagens tomográficas são parte de uma tecnologia disponível a todos os interessados por ela.

O movimento de busca por uma Odontologia baseada em evidências é irreversível, bem como o é a necessidade de uma formação sólida para gerar bons profissionais. Jovens cirurgiões-dentistas, recém-egressos das escolas de Odontologia, deveriam se candidatar a cursos de pós-graduação com elevada carga horária e que forneçam a eles a base sólida necessária para entrar com a cabeça ereta no mercado de trabalho. Essas verdades podem ser constatadas nas afirmações contidas na entrevista apresentada nesse número. Nosso entrevistado, o Dr. Turpin, editor-chefe do American Journal of Orthodontics and Dentofacial Orthopedics, ainda ressalta a relevância dos Boards de Ortodontia para o reconhecimento público de um profissional como alguém bem-sucedido.

Dessa forma, em sintonia com Asimov, as previsões que fiz não são de algo que vai ocorrer, mas daquilo que pode ocorrer. Qualquer que seja o futuro, o preparo para ele está na busca por boa formação e boa educação continuada. Jovens ortodontistas, preparem-se para ele buscando a excelência em sua formação, pois vocês são os personagens dessa ficção.

Jorge Faber

Editor chefe

faber@dentalpress.com.br 